\title{
ПЕРСОНАЛИЗИРОВАННЫЙ ПОДХОД В УПРАВЛЕНИИ САХАРНЫМ ДИАБЕТОМ 2 ТИПА: СИБУТРАМИН+ДАПАГЛИФЛОЗИН - СИНЕРГИЗМ НА СТАРТЕ. КЛИНИЧЕСКИЙ СЛУЧАЙ
}

\author{
Юрова О.В., Марченкова Л.А. \\ «СМ-Клиника», г. Москва \\ «НМИЦ реабилитачии и курортологии МЗ РФ», Москва
}

Пациент Ч., 1962 г.р. обратился в клинику к урологу с жалобами на болезненное, учащенное мочеиспускание, сухость во рту, жажду, постоянное чувство голода в дневное время.

При биохимическом исследовании крови выявлен уровень глюкозы 10,4 мМ/л натощак.

При первичном осмотре у эндокринолога был выставлен диагноз: СД2 в/в с целевым уровнем НbА менее 6,5\%.

Фон: Ожирение 1 степени.

Выводы: потенциирование эффекта дапаглифлозина и сибутрамина на старте терапии СД2 способствует формированию правильного пищевого поведения, снижению калорийности суточного рациона и, таким образом, приводит к компенсации углеводного обмена в более короткие сроки, в результате соблюдения принципа комплаентности и влияния на патофизиологические механизмы заболевания. 